\title{
Seroepidemiological study of human parvovirus B19 among human immunodeficiency virus-infected patients in a medium-sized city in Rio de Janeiro, Brazil
}

\author{
Kátia Martins Lopes de Azevedo ${ }^{1 /+}$, Sérgio Setúbal1', Luis Antônio Bastos Camacho², \\ Luis Guillermo Coca Velarde ${ }^{3}$, Solange Artimos de Oliveira ${ }^{1}$
}

\begin{abstract}
${ }^{3}$ Departamento de Estatística ${ }^{1}$ Disciplina de Doenças Infecciosas e Parasitárias, Hospital Universitário Antônio Pedro, Universidade Federal Fluminense, R. Marquês do Paraná 303 2o andar, Niterói, RJ, Brasil ²Departamento de Epidemiologia, Escola Nacional de Saúde Pública, Fundação Oswaldo Cruz-Fiocruz, Rio de Janeiro, RJ, Brasil
\end{abstract}

Parvovirus B19 (B-19) may cause chronic anaemia in immunosuppressed patients, including those infected with human immunodeficiency virus (HIV). We studied single serum samples from 261 consecutive HIV-infected patients using an enzyme immunoassay to detect $\operatorname{Ig} G$ antibodies to B-19. The seroprevalence of B-19-IgG was $62.8 \%$. The differences in seroprevalence across gender, age, educational categories, year of collection of the serum samples, clinical and antiretroviral therapy characteristics, $C D 4^{+}$count, $C D 4^{+}$and $C D 8^{+}$percentage and $C D 4^{+} C D 8^{+}$ratios were neither substantial nor statistically significant. There was a non-significant, inverse association between B-19 seropositivity and plasma HIV load and haemoglobin level. Our results indicated that $37.1 \%$ of patients might be susceptible to B-19 infection and remained at risk for being infected, mainly during epidemic periods. As B-19 infection can be treated with immune globulin preparations, it may be included in the diagnostic approach toward chronic anaemia in HIV-infected patients.

Key words: human parvovirus B19 - seroprevalence - HIV infection - anaemia

Diseases caused by parvovirus B19 (B-19) include the common childhood exanthematic disease erythema infectiosum, febrile episodes of arthropathy in adults, aplastic crisis in patients with hemolytic diseases, chronic anaemia in immunosuppressed patients and non-immune hydrops fetalis following intrauterine infection in susceptible mothers. The infection, however, is often asymptomatic. The virus has a marked tropism for erythroid progenitors and its replication may lead to pure red cell aplasia, which is usually transient and subclinical. However, in patients with impaired cellular and humoural immunity, B-19 infection may persist and ultimately render the chronic red cell aplasia clinically evident. This syndrome has been described in patients with a variety of immunodeficiency states, including human immunodeficiency virus (HIV) infection (Young \& Brown 2004).

Acute B-19 infection is thought to confer a protective, lifelong immunity. In immunocompromised patients, persistence of virus replication and the consequent chronic anaemia are due to an inability to produce neutralizing antibodies (Young \& Brown 2004). In HIV-infected individuals, the maintenance of an adequate humoural immune response until the late stages of HIV disease may explain the low frequency of chronic anaemia associated with prolonged parvovirus infection (Vernazza et al. 1996). On the other hand, HIV-infected patients with

Financial support: CNPq (305938/2006-1, 471155/03-9, 471618/2008-0) + Corresponding author:kmlazevedo@yahoo.com.br

Received 27 April 2009

Accepted 22 July 2009 no B-19-especific $\mathrm{IgG}$ antibodies remain susceptible to B-19 infection and are at risk for developing persistent anaemia when acutely infected (Zuckerman et al. 1994). Epidemiological studies have shown that B-19 activity occurs periodically, commonly in the form of outbreaks in the late spring and summer (Oliveira et al. 1996).

Anaemia is the most common hematologic abnormality observed in HIV-infected patients (Koduri 2000). There are many causes of anaemia in these patients, including coinfection with mycobacterias, fungus, cytomegalovirus or B-19; drugs, such as zidovudine, trimethoprim sulfamethoxazole or antineoplasm; lymphoma; and the direct effect of HIV on the function of accessory cells within the marrow microenvironment (Abkowitz et al. 1997). Chronic B-19 viraemia due to the failure to produce neutralising antibodies to the virus is a treatable cause of anaemia with normal globulin preparation and, therefore, its diagnosis is important in immunocompromised patients (Frickhofen et al. 1990).

The objectives of the current study are to detect the seroprevalence of IgG antibodies to B-19 and determine its association with clinical and epidemiological factors among HIV-positive patients from a large general hospital in Niterói, state of Rio de Janeiro (RJ), Brazil. The relevance of parvovirus infection has recently been acknowledged and coinfection with HIV may have significant clinical and public health implications.

\section{PATIENTS, MATERIALS AND METHODS}

The study was conducted in the Department of Infectious Diseases, Hospital Universitário Antônio Pedro, Universidade Federal Fluminense, a large tertiary public hospital in Niterói. Niterói has approximately 477,900 
inhabitants (IBGE 2008). The hospital also provides health care to other larger neighbouring municipalities and, to a lesser extent, to people from other parts of the state. The study group consisted of HIV-positive adult patients who attended the general medical outpatient clinic, which included antiretroviral therapy and followup with $\mathrm{CD}^{+} \mathrm{T}$ cell counts and plasma HIV load tests. Single serum samples were collected between November 2001-December 2003.

Sample collection and antibody assay - Blood samples were collected and the sera obtained after centrifugation of clotted samples were stored at $-20^{\circ} \mathrm{C}$. Serum samples were assigned a numerical code to conceal the identities of the study subjects. Enzyme-linked immunosorbent assays (ELISA; Biotrin International, Dublin, Ireland) were used to detect IgG antibodies to B-19 in the sera. According to the manufactures, this test has $100 \%$ sensitivity and $100 \%$ specificity. The test uses recombinant VP2 protein antigen to identify B-19-specific $\mathrm{IgG}$ antibodies.

Data analysis - Continuous variables (e.g., age, $\mathrm{CD}^{+}$ $T$ cell count, plasma HIV load) were categorised. Differences in proportions were assessed using the chi-square test and the chi-square test for linear trend, when appropriate. Data were entered and analysed using Epi Info, Version 3.5.1 (US Centers for Disease Control, 2008). Odds ratios and their 95\% confidence intervals were calculated to measure the association between B-19 seropositivity and risk factors, including demographic, clinical and antiretroviral characteristics, $\mathrm{CD}^{+} \mathrm{T}$ cell counts, $\mathrm{CD}^{+}$and $\mathrm{CD} 8^{+} \mathrm{T}$ cell percentages, $\mathrm{CD} 4^{+} / \mathrm{CD} 8^{+}$ $\mathrm{T}$ cell ratios, HIV viral load and haemoglobin level. A $5 \%$ significance level was adopted.

Ethics - Written informed consent was obtained and the project was approved by the Hospital Review Board.

\section{RESULTS}

All 261 HIV patients attending the Department of Infectious Diseases for routine care during the study period agreed to participate in the study. There were $133(51 \%)$ men (mean age: 38.5 years; range: 16-63) and 128 (49\%) women (mean age: 35.1 years; range: 16-70). A total of $40 \%(106 / 261)$ of the subjects were from a neighbouring municipality (São Gonçalo), 32\% (83/261) from Niterói, $16 \%(42 / 261)$ from other municipalities in RJ and $12 \%$ (30/261) had an unknown residence. CD4 $4^{+} \mathrm{T}$ cell counts ranged from $1 / \mathrm{mm}^{3}$ to $1061 / \mathrm{mm}^{3}$ (mean $311 / \mathrm{mm}^{3}$ ). Approximately $35 \%(91 / 261)$ of the patients had $\mathrm{CD}^{+}{ }^{+} \mathrm{T}$ bellow 200 cells $/ \mathrm{mm}^{3}$. The overall seropositivity to B-19 IgG antibodies was $62.8 \%(164 / 261)(95 \%$ CI: $56.7-68.7 \%)$. Human B-19 IgG antibody tests were equivocal in 10 $(3.8 \%)$ of sera and were disregarded in the date analysis.

The seropositivity to B-19 IgG antibodies was $66.7 \%$ among males and $63.9 \%$ among females. Higher seropositivity was observed among patients under 30 years of age $(72.7 \%)$ and who had a lower educational level $(67.5 \%)$. The differences in seroprevalence to B-19 across sex, age and educational categories were neither substantial nor statistically significant (Table).
Year of collection of the serum samples, clinical and antiretroviral therapy characteristics, $\mathrm{CD} 4^{+}$count category, $\mathrm{CD}^{+}$and $\mathrm{CD}^{+}$percentages and $\mathrm{CD} 4^{+} / \mathrm{CD}^{+}$ ratios did not appear to be associated with higher B-19 seropositivity (Table).

There was a non-significant inverse association between B-19 seropositivity and plasma HIV load and haemoglobin level (Table). Patients with HIV load $<10,000$ were 2.2 times more likely to be seropositive to B-19 compared to those with HIV load $\geq 10000(p=0.0154)$. The association was not modified by $\mathrm{CD} 4^{+} \mathrm{T}$ cell counts (data not shown).

\section{DISCUSSION}

To our knowledge, this study is the second largest reported on B-19 seroprevalence in HIV-infected patients. Van Elsacker-Niele et al. (1996) studied 317 HIVpositive patients in the Netherlands and found a specific $\mathrm{IgG}$ seroprevalence of $60.3 \%$, similar to that observed in our patients $(62.9 \%)$. Their patients had more advanced HIV disease--CD4 ${ }^{+} \mathrm{T}$ cell count levels were lower than 100 cell $/ \mathrm{mm}^{3}$ in $39.9 \%$ of them and the mean $\mathrm{CD}^{+} \mathrm{T}$ cell count was $36 / \mathrm{mm}^{3}$, whereas, in the present study, they were $21 \%$ and $311 / \mathrm{mm}^{3}$, respectively.

In a small-scale study conducted in Brazil, Aguiar et al. (2001) studied 55 HIV-infected patients attending an outpatient clinic in Niterói from September 1997-January 1998, using an indirect immunofluorescence test to detect anti-B-19 $\mathrm{IgG}$. The prevalence (91\%) was higher than that observed in our patients. In fact, we found rates similar to those obtained in larger seroprevalence studies in Brazilian immunocompetent adults, whose seropositivity rates ranged from $71.6-73.7 \%$ (Nascimento et al. 1990, Silva et al. 2006, Huatuco et al. 2008).

Gyllensten et al. (1994) searched retrospectively 69 HIV-infected patients with anaemia. Patients with HIV infection without anaemia or other HIV-related symptoms served as a control group. Similar to that observed in our patients, those authors found a 64\% B-19 seroprevalence and no difference concerning the prevalence of IgG antibodies between patients in early and late stages of HIV infection (according to $\mathrm{CD}^{+} \mathrm{T}$ cell count levels). Chernack et al. (1995) found a mean $\mathrm{CD} 4^{+} \mathrm{T}$ cell count (284/ $\mathrm{mm}^{3}$ ) that was similar to that observed in our patients $\left(254 / \mathrm{mm}^{3}\right)$, but also found a surprisingly low seroprevalence: only $7.6 \%$ of the unselected HIV-infected patients and only $18.2 \%$ of the anaemic HIV-infected patients had detectable IgG B-19-especific antibodies. These variations in seroprevalence might be explained by seasonal, epidemiological or demographical characteristics that resulted in different rates of exposure to the virus.

Two other studies reported higher B-19 seroprevalence: 96\% (Raguin et al. 1997) and 81\% (Vernazza et al. 1996). Raguin et al. (1997) found similar prevalence in anaemic and non-anaemic HIV-infected patients. They concluded that anaemia per se could not be correlated with the presence of $\operatorname{IgG}$ antibodies to B-19. In our study, although B-19 seroprevalence was higher in anaemic patients (76.3\%), the difference was not statistically significant. In the study by Vernazza et al. (1996), CD4 $4^{+} \mathrm{T}$ lymphocyte count was inversely 


\section{TABLE}

Seroprevalence of parvovirus B19 (B-19)-IgG among human immunodeficiency virus (HIV) infected-patients, according to clinical, antiretroviral therapy and laboratory parameters - Niterói, Rio de Janeiro, 2001-2003

\begin{tabular}{|c|c|c|c|c|}
\hline Characteristic & $\mathrm{n}$ & $\begin{array}{l}\text { Seropositive for } \\
\text { B-19-IgG } \\
\text { n }(\%)\end{array}$ & $95 \% \mathrm{CI}$ & $\mathrm{p}$-value \\
\hline Age groups (years) & & & & $0.1785^{a}$ \\
\hline$<30$ & 66 & $48(72.7)$ & $60.4-83.0$ & $0.4581^{b}$ \\
\hline $30-39$ & 93 & $53(56.9)$ & $46.3-67.2$ & \\
\hline $40-49$ & 65 & $45(69.2)$ & $56.6-80.1$ & \\
\hline$\geq 50$ & 27 & $18(66.7)$ & $46.0-83.4$ & \\
\hline Educational level & & & & $0.9235^{a}$ \\
\hline Elementary & 114 & $77(67.5)$ & $58.1-76.0$ & \\
\hline High school and college & 55 & $36(65.5)$ & $51.4-77.8$ & \\
\hline Unknown & 82 & $51(62.2)$ & & \\
\hline Serum sample collect year & & & & $0.4747^{a}$ \\
\hline $2002^{c}$ & 188 & $120(63.8)$ & $56.5-70.7$ & \\
\hline 2003 & 63 & $44(69.8)$ & $57.0-80.8$ & \\
\hline Clinical characteristics & & & & $0.1612^{a}$ \\
\hline Asymptomatic & 65 & $47(72.3)$ & $59.8-82.6$ & \\
\hline HIV related complex & 21 & $16(76.2)$ & $52.8-91.7$ & \\
\hline HIV & 152 & $93(61.2)$ & $52.9-68.9$ & \\
\hline Unknown & 13 & $8(61.5)$ & & \\
\hline Antiretroviral therapy & & & & $0.6073^{a}$ \\
\hline Yes & 138 & $84(60.9)$ & $52.2-69.1$ & \\
\hline No & 98 & $72(73.5)$ & $63.6-81.9$ & \\
\hline Unknown & 15 & $8(53.3)$ & & \\
\hline $\mathrm{CD}^{+}$cell count $/ \mathrm{mm}^{3}$ & & & & $0.5608^{a}$ \\
\hline$\leq 50$ & 20 & $15(75.0)$ & $50.9-91.3$ & $0.9305^{b}$ \\
\hline $51-100$ & 34 & $20(68.8)$ & $40.7-75.4$ & \\
\hline $101-200$ & 38 & $22(57.9)$ & $40.8-73.7$ & \\
\hline $201-350$ & 63 & $44(69.8)$ & $57.0-80.8$ & \\
\hline$>350$ & 88 & $56(63.6)$ & $52.7-73.6$ & \\
\hline Unknown & 8 & $7(87.5)$ & & \\
\hline $\mathrm{CD}^{+}$cell percentage & & & & $0.8341^{a}$ \\
\hline$<14$ & 92 & $59(64.1)$ & $53.5-73.9$ & \\
\hline $14-28$ & 98 & $66(67.3)$ & $57.1-76.5$ & \\
\hline$>28$ & 20 & $14(70.0)$ & $45.7-88.1$ & \\
\hline Unknown & 41 & $25(60.9)$ & & \\
\hline $\mathrm{CD}^{+}$cell percentage & & & & $0.6806^{a}$ \\
\hline$<21$ & 3 & $2(66.7)$ & $9.4-99.2$ & \\
\hline $21-37$ & 20 & $15(75.0)$ & $50.9-91.3$ & \\
\hline$>37$ & 187 & $122(65.2)$ & $58.0-72.0$ & \\
\hline Unknown & 41 & $25(60.9)$ & & \\
\hline $\mathrm{CD}^{+} / \mathrm{CD}^{+}$cell ratio & & & & $0.8304^{a}$ \\
\hline$<1$ & 233 & $151(64.8)$ & $53.3-70.9$ & \\
\hline$\geq 1$ & 9 & $5(55.6)$ & $21.2-86.6$ & \\
\hline Unknown & 9 & $8(88.9)$ & & \\
\hline Plasma HIV load (copies/mL) & & & & $0.0725^{a}$ \\
\hline$<1000$ & 66 & $47(71.2)$ & $58.8-81.7$ & $0.3030^{b}$ \\
\hline $1000-9999$ & 28 & $21(75.0)$ & $55.1-89.3$ & \\
\hline $10000-99999$ & 61 & $32(52.4)$ & $39.3-65.4$ & \\
\hline$\geq 100000$ & 33 & $19(57.5)$ & $39.2-74.5$ & \\
\hline Unknown & 63 & $45(71.4)$ & & \\
\hline Haemoglobin $(\mathrm{g} / \mathrm{dL})$ & & & & $0.0787^{a}$ \\
\hline$\leq 12.5$ & 80 & $61(76.3)$ & $65.4-85.1$ & \\
\hline$>12.5$ & 88 & $55(62.5)$ & $51.5-72.6$ & \\
\hline Unknown & 83 & $48(57.8)$ & & \\
\hline
\end{tabular}


related to seroprevalence rates, but this trend was not statistically significant. This inverse association was not observed in our study, although a higher seroprevalence rate $(75 \%)$ was found among those patients that were severely immunocompromised $\left(\mathrm{CD}^{+} \mathrm{T}\right.$ cell count $<50 / \mathrm{mm}^{3}$ ). Chernack et al. (1995) recommended the investigation of B-19 infection in anaemic HIV-infected patients. However, the difference in seroprevalence, on which they based their inference, was not controlled for confounding from other variables.

Interestingly, we found an inverse - but non-significant - association between B-19 seropositivity and plasma HIV load. This unexpected observation may indicate an increased susceptibility to B-19 infection in patients with low plasma HIV load or, perhaps, a greater ability to mount a specific antibody response in individuals whose immune system is not weakened by HIV activity. This seems to occur independently from $\mathrm{CD} 4^{+} \mathrm{T}$ cell counts, as we found no significant association between such counts and B-19 seropositivity. To our knowledge, no other study evaluated B-19 seroprevalence in HIVinfected patients versus plasma HIV load.

Our study has some limitations. The results were based on cross-sectional data from HIV-positive patients who may not represent the hypothetical original cohort of patients, among whom losses were not random. However, this is unlikely to affect our results as B-19 infection does not seem to interfere with the survival of HIVpositive individuals. In addition, current data are based on HIV-positive patients selected from a public hospital, who may not have been truly representative of the HIVpositive population of the municipalities of study from which they came. On the other hand, there is no reason to suppose that B-19-infected individuals would be more likely to be seen at our hospital. These selection factors limit the generalisability of our estimates of B-19 infection rates. This was an exploratory study based on data available from a limited number of patients. Weak associations and a small sample size precluded the control of confounding through multivariate analysis. Reciprocal changes in the natural history of HIV and B-19 infections could not be fully assessed in this setting.

In conclusion, the prevalence of anti-B-19 IgG antibodies in HIV-infected patients was $62.9 \%$, which is in accordance with large-scale studies in the medical literature. In addition, $37.1 \%$ of our patients might have been susceptible to B-19 infection and remained at risk for infection by person-to-person contact or blood transfusion. Therefore, the presence of red cell aplasia in HIV-infected patients with advanced immunodeficiency, especially during B-19 epidemics, should alert physicians to the possibility of B-19 infection, which is a cause of anaemia responsive to intravenous immunoglobulin therapy in HIV-infected patients. There is no evidence of increased susceptibility of HIV-positive subjects to B-19 infection.

\section{ACKNOWLEDGEMENTS}

To Dr. Jussara P Nascimento (in memoriam), from Universidade Federal Fluminense (UFF), for providing human parvovirus tests, to Valéria Ferreira da Silva, from UFF, for techni- cal help, and to the general practitioners from the Department of Infectious Diseases, Hospital Universitário Antônio Pedro, for clinical support.

\section{REFERENCES}

Abkowitz JL, Brown KE, Wood RW, Kovach NL, Green SW, Young NS 1997. Clinical relevance of parvovirus B19 as a cause of anemia in patients with human immunodeficiency virus infection. J Infect Dis 176: 296-273.

Aguiar FS, Lopes DP, Bazin AR, Setúbal S, Cohen BJ, Nascimento JP 2001. Human parvovirus B19 infection in HIV-positive patients. Rev Soc Bras Med Trop 34: 239-242.

Chernak E, Cubbin G, Henry D, Naides SJ, Hodinka RL, Macgregor RR, Friedman HM 1995. Infection due to parvovirus B19 in patients infected with human immunodeficiency virus. Clin Infect Dis 20: 170-173.

Frickhofen N, Abkowitz JL, Safford M, Berry M, Antunez-deMayolo J, Astrow A, Cohen R, Halperin I, King L, Mintzer D, Cohen B, Young NS 1990. Persistent B19 parvovirus infection in patients infected with human immunodeficiency virus type 1 (HIV-1): a treatable cause of anemia in AIDS. Ann Intern Med 113: 926-933.

Gyllensten K, Sönnerborg A, Jorup-Rönström C, Halvarsson M, Yun Z 1994. Parvovirus B19 infection in HIV-1 infected patients with anemia. Infection 22: 356-358.

Huatuco EM, Durignon EL, Lebrun FLAS, Passos SD, Gazeta RE, Azevedo Neto RS, Massad E 2008. Seroprevalence of human parvovirus B19 in a suburban population in São Paulo, Brazil. Rev Saude Publ 42: 443-449.

IBGE - Instituto Brasileiro de Geografia e Estatística 2008. Estimativas da população para $1^{\circ}$ de julho de 2008. Available from: http:// www.ibge.gov.br. [accessed 9 december 2008].

Koduri PR 2000. Parvovirus B19-related anemia in HIV-infected patients. AIDS Patient Care STDS 14: 7-11.

Nascimento JP, Buckley MM, Brown KE, Cohen BJ 1990. The prevalence of antibody to human parvovirus B19 in Rio de Janeiro, Brazil. Rev Inst Med Trop Sao Paulo 32: 41-45.

Oliveira AS, Brandão AB, Fernandes DG, Bettini LR, Carvalho AB, Pereira ACM, Azevedo KML, Nascimento JP 1996. Human parvovirus B19 infection: clinical and epidemiological study of 24 cases. Rev Inst Med Trop Sao Paulo 38: 323-327.

Raguin G, Leruez-Ville M, Gregoir V, Deplanche M, Leport C, Morinet F, Vilde JL 1997. Low prevalence of active parvovirus B19 infection in HIV-infected patients. Eur J Clin Microbiol Infect Dis 16: 760-762.

Silva ARA, Nogueira AS, Alzeguir JCL, Costa MCFL, Nascimento JP 2006. Prevalência de anticorpos IgG antiparvovirus B19 em gestantes durante o atendimento pré-natal e casos de hidropisia fetal não imune atribuídos ao parvovírus B19, na cidade do Rio de Janeiro. Rev Soc Bras Med Trop 39: 467-472.

Van Elsacker-Niele AMW, Kroon FP, Van der Wende ME, Salimans MMM, Spaan WJM, Kroes ACM 1996. Prevalence of parvovirus B19 infection in patients infected with human immunodeficiency virus. Clin Infect Dis 23: 1255-1260.

Vernazza PL, Pfister LA, Siegl G, Cassinotti P 1996. High seroprevalence of parvovirus B19 among patients infected with human immunodeficiency virus. Clin Infect Dis 22: 198-199.

Young NS, Brown KE 2004. Mechanisms of disease parvovirus B19. N Engl J Med 350: 586-597.

Zuckerman MA, Williams I, Bremner J, Cohen B, Miller RF 1994. Persistent anaemia in HIV-infected individuals due to parvovirus B19 infection. AIDS 8: 1191-1192. 